\title{
ANALISIS PENERAPAN 8 STANDAR NASIONAL PENDIDIKAN PADA SMP NEGERI 2 DOLOPO KABUPATEN MADIUN
}

\author{
Luki Eko Cahyono, Satrijo Budiwibowo dan Juli Murwani \\ Program Studi Pendidikan Akuntansi - FPIPS \\ IKIP PGRI MADIUN
}

\begin{abstract}
ABSTRAK
Standar nasional pendidikan adalah kriteria minimum yang harus dipenuhi dalam pelaksanaan pendidikan. Standar Nasional Pendidikan meliputi Standar Isi, Standar Proses, Standar Kompetensi Lulusan, Standar Pendidik dan Tenaga Kependidikan, Standar Sarana Prasarana, Standar Pengelolaan, Standar Pembiayaan, Standar Penilaian. Untuk menjaga kualitas pendidikan, konsistensi dari fungsi dan tujuan pendidikan, maka kurikulum, proses pembelajaran, maupun manajerial secara keseluruhan harus mengacu dan berpedoman pada Standar Nasional Pendidikan. Tujuan dalam penelitian ini adalah (1) Mengetahui Penerapan 8 Standar Nasional pada SMP Negeri 2 Dolopo (2) Memberikan Masukan berdasarkan temuan tentang penerapan 8 Standar Nasional Pendidikan guna Meningkatkan kualitas pendidikan pada SMP Negeri 2 Dolopo.
\end{abstract}

Penelitian ini menggunakan desain penelitian Deskriptif Kualitatif. Jenis penelitian adalah studi kasus. Data yang digunakan adalah data Primer. Teknik pengumpulan data yang digunakan adalah wawancara dan dokumentasi. Teknik keabsahan data adalah Triangulasi Sumber dan teknik analisis data yang digunakan adalah pendekatan Strengths, Weakness, Opportunities, dan Threats (Analisis SWOT). Kesimpulan penelitian ini adalah (1) Hasil analisis Strenght (Kekuatan) adalah sekolah sudah merencanakan, melaksanakan dan mengevaluasi sebagian besar indikator dalam pemenuhan Standar Nasional Pendidikan sehingga meningkatkan mutu pendidikan sekolah. (2) Hasil analisis Weakness (kelemahan adalah keterbatasan anggaran dana dan sumber daya manusia baik peserta didik, pendidik, maupun tenaga kependidikan dalam pemenuhan seluruh unsur Standar Nasional Pendidikan. (3) Hasil analisis Opportunities (peluang) adalah Pemberian workshop dan pelatihan kepada pendidik dan tenaga kependidikan meningkatkan kualitas pendidikan sekolah, dan perencanaan, pelaksanaan pembiayaan serta evaluasi penganggaran yang baik memberikan dampak positif terhadap semua unsur operasional sekolah maupun sarana prasarana sekolah. (4) Hasil analisis Threats (Tantangan) adalah perencanaan, sosialisasi, pelaksanaan dan evaluasi serta tindak lanjut yang tidak dijalankan dengan manajemen yang baik dalam upaya pemenuhan Standar Nasional Pendidikan akan menghambat peningkatan kualitas pendidikan sekolah. (5) Hasil penerapan Standar Nasional Pendidikan pada SMP Negeri 2 Dolopo menggunakan analisis SWOT menunjukkan bahwa Kekuatan lebih besar daripada Kelemahan dan Peluang lebih besar dari Ancaman, yang berarti Standar Nasional Pendidikan telah terpenuhi dan menghasilkan Akreditasi Sekolah nilai A

Kata Kunci : Standar Nasional Pendidikan, SMP N 2 Dolopo, SWOT, Madiun

\section{PENDAHULUAN}

Salah satu ciri negara yang maju adalah negara yang mempunyai kualitas pendidikan yang baik. Pendidikan menjadi tolak ukur kesuksesan dan berkembangnya suatu bangsa atau negara.

Di Indonesia saat ini, pendidikan menjadi hal yang sangat ramai diperbincangkan, tak sekedar membahas tentang bagaimana siswa dapat lulus sekolah, tapi juga bagaimana proses pembelajaran dilaksanakan dengan baik dan dapat mencerdaskan peserta didik sebagai generasi penerus bangsa. Persoalan pendidik pun sangat komplek salah satunya kualitas guru 
yang dirasa kurang, kualitas yang dirasa kurang ini menjadi awal permasalah baru seperti pelaksanaan proses pembelajaran kurang efektif dan efisien dikarenakan kurang maksimalnya proses perencanaan pembelajaran.

Guru merupakan salah satu unsur penting pendidikan indonesia. Hal ini sudah tidak diragukan lagi, ditangan guru lah pendidikan bisa menjadi senjata untuk Indonesia yang lebih baik dan lebih maju lagi. Guru sebagai pelaksana pendidikan yang merencanakan, melaksanakan dan mengevaluasi proses pendidikan harus bisa melaksanakan hal tersebut dengan baik dan terintegrasi pada kurikulum yang berlaku saat ini.

Kurikulum adalah seperangkat rencana dan pengaturan mengenai tujuan, isi, dan bahan pelajaran serta cara yang digunakan sebagai pedoman penyelenggaraan kegiatan pembelajaran untuk mencapai tujuan pendidikan tertentu. Dalam kurikulum tercakup tujuan pendidikan yang akan dicapai guna kualitas pendidikan yang lebih baik lagi, oleh karena itu peran guru sebagai pendidik, peserta didik, dan kurikulum itu sendiri sangat lah berperan penting. Akan tetapi fakta dilapangan berbanding terbalik, peran guru, peserta didik dan kurikulum itu sendiri kurang bisa terorganisasi dengan baik karena berbagai masalah yang muncul. Pembiayaan pendidikan merupakan unsur pendorong pelaksanaan pendidikan yang memenuhi segala kebutuhan dalam operasional pendidikan. Pendidikan yang yang berkualitas tak terlepas dari semua sarana dan prasaran yang menunjang terlaksananya pendidikan secara efektif.

Sekolah sebagai unit pendidikan, mempunyai kewajiban melaksanakan pendidikan yang berkualitas yang memenuhi kebutuhan manusia Indonesia. Tak salah jika sekolah adalah ujung tombak pendidikan, karena sekolah lah yang melaksanakan pembelajaran, mengurus pendanaan dan mengelola administrasi pendidikan, serta merencanakan, melaksanakan dan mengevaluasi kurikulum yang dijalankan. SMP Negeri 2 Dolopo merupakan salah satu Sekolah Menengah Pertama lingkup Dinas Pendidikan Kabupaten. Dalam perjalanannya sejak berdiri tahun 1979 telah banyak mengukir prestasi akademis maupun non akademis, pada bidang akademis SMP Negeri 2 Dolopo berkembang menjadi sekolah yang membanggakan dengan prestasi yang diraih dalam beberapa tahun terakhir. Selain berprestasi dibidang Akademik, prestasi non akademik pun juga tak kalah membanggakan, hal ini dibuktikan dengan banyaknya piala dan tropy yang tertata rapi ditempat penyimpanannya.

Permasalahan yang sering muncul dalam pendidikan adalah konsistensi menjaga kualitas pendidikan termasuk pada SMP Negeri 2 Dolopo, dalam menjaga konsistensi kualitas pendidikan Badan Standar Nasional Pendidikan (BSNP) telah mencanangkan standarisasi Pendidikan Nasional dengan 8 Standar Nasional Pendidikan yang harus dipenuhi setiap satuan pendidikan atau sekolah.

Standar nasional pendidikan adalah kriteria minimum yang harus dipenuhi dalam pelaksanaan pendidikan. Standar Nasional Pendidikan berfungsi sebagai dasar dalam perencanaan, pelaksanaan, dan pengawasan pendidikan dalam rangka mewujudkan pendidikan nasional yang bermutu. Serta bertujuan menjamin mutu pendidikan nasional dalam rangka mencerdaskan kehidupan bangsa dan membentuk watak serta peradaban bangsa yang bermartabat. Untuk menjaga konsistensi dari fungsi dan tujuan tersebut, maka kurikulum, proses pembelajaran, maupun manajerial secara keseluruhan harus mengacu dan berpedoman pada Standar Nasional Pendidikan.

SMP Negeri 2 Dolopo yang sejak dahulu terkenal akan sekolah dengan citra kualitas yang kurang baik dimata masyarakat, beberapa tahun belakangan menjadi bahan perbincangan yang cukup hangat. Hal ini dikarenakan Akreditasi sekolah yang didapat adalah nilai akreditasi yang tinggi yaitu Akreditasi A, pola pikir masyarakat mulai menganggap kualitas pendidikan pada SMP Negeri 2 Dolopo sudah mengalami peningkatan yang signifikan dan mulai berfikir menyekolahkan putra/putrinya di sekolah tersebut. 
Dari permasalahan diatas, penulis merasa tertarik melakukan penelitian dengan judul "Analisis Penerapan 8 Standar Nasional Pendidikan Pada SMP Negeri 2 Dolopo - Kab. Madiun".

\section{METODE PENELITIAN}

1. Tempat Penelitian

Penulis melakukan penelitian studi kasus Standar Nasional Pendidikan di SMP Negeri 2 Dolopo Jalan Abimanyu No.79 Dolopo, Kab. Madiun yang berada dalam naungan Dinas Pendidikan Kabupaten Madiun.

2. Waktu Penelitian

Waktu penelitian dilaksanakan pada semester gasal pada bulan September 2014 sampai bulan Februari 2015

3. Pendekatan dan Jenis Penelitian

Sesuai dengan tujuan penulis, maka penelitian ini menggunakan desain penelitian Deskriptif Kualitatif untuk mengetahui Implementasi Standar Nasional Pendidikan dalam rangka peningkatan kualitas pendidikan pada SMP Negeri 2 Dolopo, Kab. Madiun.

Dalam penelitian ini digunakan teknik analisis deskriptif kualitatif. Analisis Deskriptif Kualitatif yaitu dengan memberikan ulasan atau interpretasi terhadap data yang diperoleh sehingga menjadi jelas dan bermakna dibandingkan dengan sekedar angka-angka. Langkah-langkahnya adalah reduksi data, penyajian data dengan bagan - bagan dan teks, kemudian penarikan kesimpulan. Jenis penelitian yang dilakukan adalah penelitian studi kasus.

4. Sumber Data

Dalam penelitian ini peneliti hanya menggunakan data primer. Data primer adalah data yang diperoleh atau dikumpulkan langsung dari obyek penelitian oleh orang yang melakukan penelitian. Data primer disebut juga data asli atau data baru. Adapun data primer yang akan diperoleh yaitu data standar isi, data standar proses, data standar kompetensi lulusan, data tenaga pendidik dan kependidikan, standar sarana dan prasarana, standar pengelolaan, standar pembiayaan dan standar penilaian yang terjadi tahun pelajaran 2013/2014 serta profil SMP Negeri 2 Dolopo.

5. Teknik Pengumpulan Data

\section{a. Wawancara}

Norman dan Yvonna (dalam Dariyatno, 2009:495) menjelaskan wawancara adalah metode pengumpulan jawaban atau informasi yang dilakukan dengan memberi pertanyaan langsung responden dalam masalah yang terkait. Dalam penelitian ini pihak - pihak yang akan diwawancarai adalah Kepala SMP Negeri 2 Dolopo

b. Dokumentasi

Norman dan Yvonna (dalam dariyatno, 2009:544) dalam bukunya yang berjudul Handbook Of Qualitative Research mengungkapkan bahwa dokumentasi merupakan teknologi personal yang berisi, catatan baik berupa surat, buku harian ataupun catatan. Dari pengertian ahli di atas disimpulkan bahwa dokumentasi merupakan pengumpulan data-data yang terkait dengan internal sekolah yakni menggunakan dokumen Evaluasi Diri Sekolah (EDS) dan Rencana Kerja Sekolah (RKS).

6. Teknik Keabsahan Data

Data kualitatif harus menggunakan teknik keabsahan data sebelum dilakukan analisis agar data benar-benar valid. Pengecekan data merupakan bagian yang penting dalam siklus penelitian karena merupakan proses meyakinkan pembaca bahwa data yang ditemukan penulis benar-benar sah.

Usaha yang dapat ditempuh oleh peneliti untuk memperoleh keabsahan temuan penelitian adalah dengan meneliti kredibilitas temuan dengan menggunakan teknik-teknik 
perpanjangan kehadiran di lapangan, observasi yang diperdalam, triangulasi (menggunakan beberapa sumber, metode, peneliti, teori), pembahasan sejawat, analisis kasus negative, pelacakan kesesuaian hasil dan pengecekan anggota (Wahidmurni, 2008:47).

Teknik keabsahan data yang digunakan penulis dalam penelitian ini adalah metode triangulasi sumber, yaitu memngunakan berbagai sumber data seperti dokumen, arsip untuk membandingkan dengan hasil wawancara dengan kepala urusan Kurikulum SMP Negeri 2 Dolopo.

7. Teknik Analisis Data

Metode analisis data merupakan cara yang utama digunakan untuk mengolah data yang terkumpul sehingga menghasilkan suatu kesimpulan yang dapat dipertanggung jawabkan. Dalam penelitian ini penulis penggunakan analisis SWOT dan analisis Arti PentingKinerja (Importance Performance Analysis). Analisis SWOT yaitu merupakan salah satu pendekatan untuk menggambarkan kondisi dan mengevaluasi suatu masalah, proyek atau konsep bisnis yang berdasarkan factor internal (dalam) dan faktor eksternal (luar) yaitu Strengths, Weakness, Opportunities, dan Threats. Berdasarkan Kotler dan keller (dalam Bob Sabran, 2009 : 57) Analisis Arti Penting-Kinerja (Importance Performance Analysis) menentukan peringkat berbagai elemen kelompok jasa dan mengidentifikasi tindakan apa yang diperlukan.

Analisis Arti Penting-Kinerja (Importance Performance Analysis) di dalam penelitian ini digunakan untuk mengetahui posisi sekolah sekolah sesuai hasil kekuatan, kelemahan, peluang dan ancaman.

Diagram Cartesius SWOT

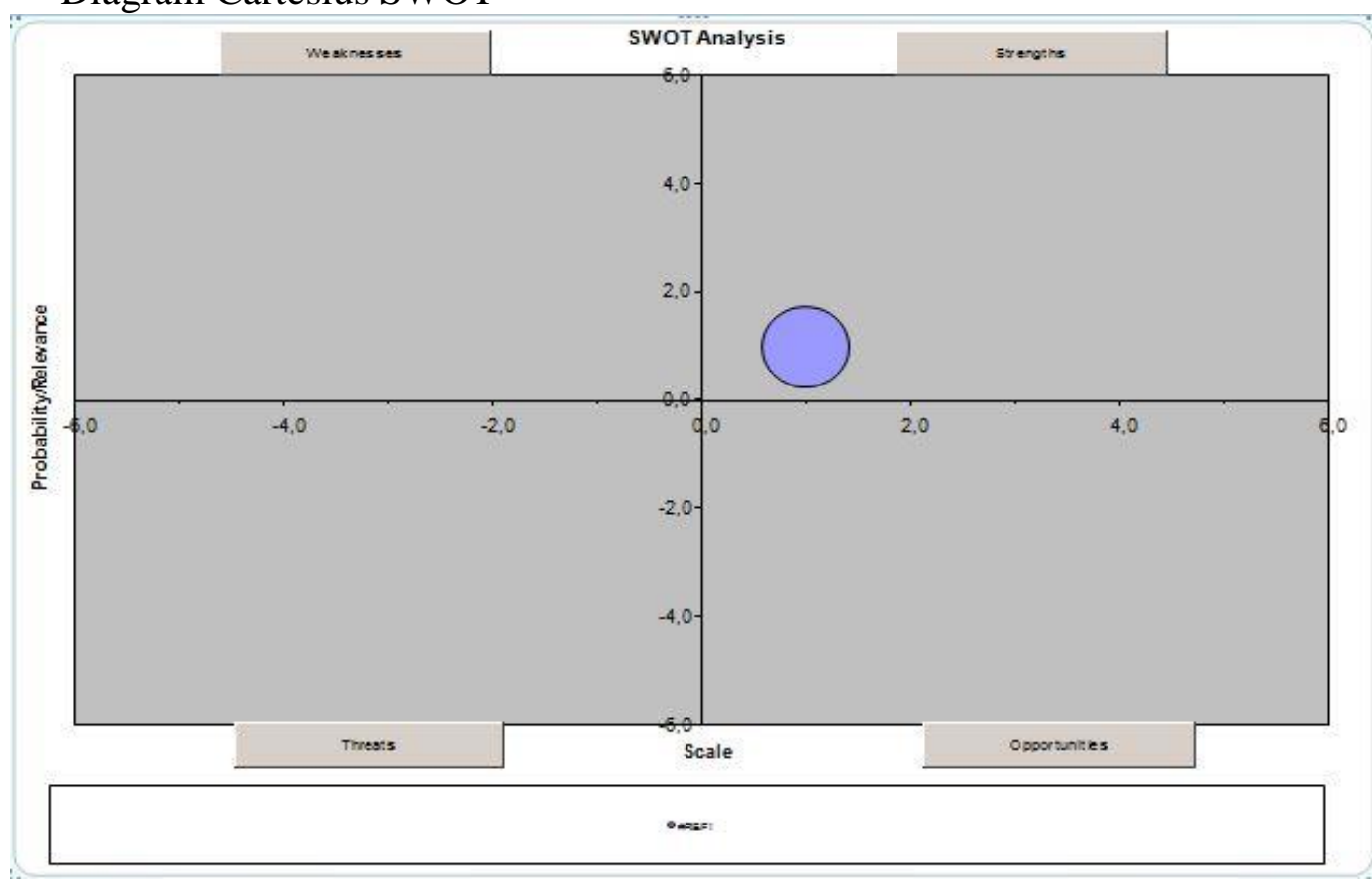

\section{TEMUAN PENELITIAN}

\section{a. Standar Isi}

Dokumen kurikulum sekolah sudah disusun dan disahkan sejak tahun 2008. Kurikulum dikembangkan menggunakan panduan BSNP dengan mempertimbangkan karakteristik daerah, social budaya sekitar, kualitas peserta didik. Kurikulum menunjukkan alokasi waktu, rencana program remedial, dan pengayaan bagi siswa. Kurikulum juga mencakup program kegiatan pengembangan diri, baik melalui bimbingan konseling maupun ekstra 
kulikuler. Sekolah telah memiliki tim pengembang kurikulum, oleh karena itu setiap tahunnya diadakan evaluasi kurikulum.

Proses penyusunan standar isi dengan memperhatikan indicator di atas, sekolah harus menyediakan layanan bimbingan dan konseling untuk memenuhi kebutuhan pengembangan pribadi peserta didik. Serta penyediaan kegiatan ekstrakurikuler dalam upaya untuk memenuhi kebutuhan pengembangan diri peserta didik.

Kurikulum telah disusun oleh Tim Pengembang kurikulum yang memuat 5 (lima) kelompok mata pelajaran yang didasarkan pada pengembangan kurikulum sesuai 7(tujuh) prinsip pelaksanaan kurikulum.

\section{b. Standar Proses}

Pendidik di SMP Negeri 2 Dolopo telah menyusun perencanaan pembelajaran mulai dari Prota, Promes, Silabus dan RPP sesuai dengan intruksi yang telah di sampaikan Kepala Sekolah yang dibantu wakil kepala sekolah bidang kurikulum. Sebagian besar pendidik masih menggunakan metode ceramah dalam melaksanakan pembelajarannya tetapi tak sedikit yang telah melaksanakan metode pembelajaran yang inovatif, salah satunya menggunakan media pembelajaran berbasis IT.

Penyusunan RPP telah memperhatikan perbedaan gender, kemampuan awal, tahap intelektual, minat, bakat, motivasi belajar, potensi, kemampuan sosial, emosional, gaya belajar, kebutuhan khusus, kecepatan belajar, latar belakang budaya, norma, nilai-nilai, dan lingkungan peserta didik. Tetapi masih ada guru yang belum menerapkan prinsipprinsip PAKEM/CTL karena kualitas SDM pendidik yang masih perlu ditingkatkan. Oleh karena itu sekolah akan memfasilitasi peningkatan kualitas SDM pendidik melalui diklat, workshop dan sebagainya.

\section{c. Standar Kompetensi Lulusan}

Kriteria Ketuntasan Minimal (KKM) yang ditetapkan oleh sekolah telah dicapai oleh pesera didik baik dalam pencapaian KKM setiap pelajaran maupun dari ujian nasional. Peserta didik memperlihatkan kemajuan yang lebih baik dalam mencapai target yang ditetapkan SKL setiap tahunnya, hal ini dibuktikan dengan tingkat kelulusan yang mencapai $100 \%$ pada tahun pelajaran 2012/2013 dan 2013/2014 akan tetapi nilai cenderung tidak konsisten. pencapaian tersebut didapat tidaklah mudah, Sekolah menfasilitasi para peserta didik untuk dapat meningkatkan hasil belajar melalui program pengayaan, Sekolah menfasilitasi peningkatan nilai UN dengan menambah jam belajar di luar jam efektif sekolah dan mengadakan ulangan mata pelajaran UN tiap hari senin pada waktu diluar jam pelajaran.

Program pengembangan diri untuk mengembangkan kepribadian, keterampilan hidup, nilai-nilai agama dan budaya peserta didik telah dilakukan melalui kegiatan pengembangan kepribadian peserta didik berupa Keagamaan, Kepramukaan, Upacara Bendera dan konseling. Tetapi tidak semua peserta didik berkepribadian sesuai dengan nilai dan norma yang berlaku di lingkungan sekolah dan lingkungan masyarakat, Sebagian peserta didik masih berperilaku sesuai dengan kebiasaan yang berlaku di lingkungan mereka, meskipun kebiasaan tersebut kurang tepat dalam dunia pendidikan. Sekolah senantiasa memfasilitasi peserta didik mengembangkan kepribadian, keterampilan hidup, nilai-nilai agama dan budaya.

\section{d. Standar Pendidik dan Tenaga Kependidikan}

SMP Negeri 2 Dolopo memiliki pendidik yang berjumlah 41 orang, jumlah ini telah memenuhi standar yang telah ditentukan. Pera pendidik itu telah berkualifikasi guru sebagai berikut : Berijazah S1 sebanyak 40 orang dengan presentase $98 \%$, Berijazah S2 
sebanyak 1 orang dengan presentase $2 \%$. Dari jumlah tersebut, 38 orang (93\%) diantaranya telah bersertifikasi pendidik dan 3 orang (7\%) belum bersertifikasi pendidik. Dari data diatas, sekolah memfasilitasi peningkatan kualifikasi dan peningkatan kompetensi kepala sekolah dan pendidik/guru secara berkelanjutan.

\section{e. Standar Sarana dan Prasarana}

Faktor penentu kualitas pendidikan yang baik selain ditentukan oleh proses pembelajaran yang baik tetapi juga factor kenyamanan sarana prasarana juga sangat menunjang terbentuknya kualitas pendidikan yang baik. Kondisi sekolah sudah memenuhi standar nasional khususnya ruang kelas, laboratorium IPA, ruang guru, ruang perpustakaan, ruang tata usaha, ruang konseling. Meskipun demikian ruang kelas belum dilengkapi tempat cuci tangan, peralatan pendidikan dalam Lab. IPA belum lengkap dan belum adanya mebeler, sarana ruang guru kurang luas sehingga rasio dengan jumlah guru tidak memadai, buku referensi dalam ruang perpustakaan belum lengkap, ruang TU masih kurang luas, perlengkapan konseling belum lengkap serta Sekolah belum memiliki kelengkapan sistem proteksi pasif dan aktif terhadap bahaya petir dan kebakaran. Oleh karena itu sekolah akan memfasilitasi penambahan sarana dan prasarana secara bertahap.

\section{f. Standar Pengelolaan}

Sekolah memiliki visi, misi dan tujuan yang jelas, yang telah diimplementasikan baik dalam RKS maupun RKAS. RKS dan RKAS telah dibuat oleh kepala sekolah, guru, staf TU, dan komite sekolah serta telah disahkan oleh dinas pendidikan kabupaten madiun. Akan tetapi belum disosialisasikan kepada seluruh warga sekolah dan belum diadakan review berkala terhadap RKS dan RKAS. Oleh karena itu sekolah akan memfasilitasi evaluasi terhadap kinerja sekolah serta akan mensosialisasikan kepada warga sekolah dan seluruh pemangku kepentingan.

\section{g. Standar Pembiayaan}

Sekolah dalam pengelolaan keuangan merujuk pada ketentuan yang berlaku, mulai dari perencanaan ( RAPBS dan RKAS), pembukuan dan pelaporan, namun pembelanjaan keuangan belum sesuai dengan perencanaan. Disamping itu tidak semua warga sekolah dapat mengakses dengan mudah pengelolaan keuangan sekolah.oleh karena itu sekolah akan memfasilitasi pengelolaan keuangan yang efektif, transparan dan akuntabel.

\section{h. Standar Penilaian Pendidikan}

Sekolah merencanakan penilaian proses dan hasil belajar peserta didik serta menginformasikan kepada peserta didik. Sekolah juga melaksanakan penilaian dengan berbagai teknik, bentuk, dan jenis penilaian, walaupun belum optimal.

Penilaian pencapaian kompetensi dasar peserta didik dilakukan berdasarkan indicator. Dengan menggunakan tes dan non tes dalam bentuk tertulis maupun lisan, pengamatan kinerja, pengukuran sikap, penilaian hasil karya berupa tugas, proyek atau produk, menggunakan porto folio dan penilaian diri.

\section{KESIMPULAN}

Dari temuan penelitian dan rumusan masalah kesimpulan penelitian ini adalah : (1) Hasil analisis Strenght (Kekuatan) dalam penerapan 8 SNP pada SMP Negeri 2 Dolopo adalah sekolah sudah merencanakan, melaksanakan dan mengevaluasi sebagian besar indikator dalam pemenuhan Standar Nasional Pendidikan. (2) Hasil analisis Weakness (kelemahan) dalam penerapan 8 SNP pada SMP Negeri 2 Dolopo adalah keterbatasan anggaran dana dan 
sumber daya manusia baik peserta didik, pendidik, maupun tenaga kependidikan dalam pemenuhan seluruh unsur Standar Nasional Pendidikan. (3) Hasil analisis Opportunities (peluang) dalam penerapan 8 SNP pada SMP Negeri 2 Dolopo adalah Pemberian workshop dan pelatihan kepada pendidik dan tenaga kependidikan meningkatkan kualitas pendidikan sekolah, dan perencanaan, pelaksanaan pembiayaan serta evaluasi penganggaran yang baik memberikan dampak positif terhadap semua unsur operasional sekolah maupun sarana prasarana sekolah. (4) Hasil analisis Threats (Ancaman) dalam penerapan 8 SNP pada SMP Negeri 2 Dolopo adalah perencanaan, sosialisasi, pelaksanaan dan evaluasi serta tindak lanjut yang tidak dijalankan dengan manajemen yang baik dalam upaya pemenuhan Standar Nasional Pendidikan akan menghambat pelaksanaan dan peningkatan kualitas pendidikan sekolah. (5) Hasil penerapan Standar Nasional Pendidikan pada SMP Negeri 2 Dolopo menggunakan analisis SWOT menunjukkan bahwa Kekuatan lebih besar daripada Kelemahan dan Peluang lebih besar dari Ancaman, yang berarti Standar Nasional Pendidikan telah terpenuhi dan menghasilkan Akreditasi Sekolah nilai A.

\section{DAFTAR PUSTAKA}

Bachri, Bachtiar S. 2010. "Meyakinkan Validitas Data Melalui Triangulasi Pada Penelitian Kualitatif”. Jurnal Teknologi Pendidikan, Vol. 10 No.1. Surabaya : Universitas Negeri Surabaya

Denzin, Norman K. \& Lincoln, Yvonna S. (Eds). 2000. Handbook Of Qualitative Research. Terjemahan oleh dariyatno. 2009. Yogyakarta : Pustaka Pelajar

Gabriel Amin Silalahi. 2003. Metodologi Penelitian dan Studi Kasus. Sidoarjo : Citra Media

Mulyasa. H. E. 2008. Implementasi Kurikulum Tingkat Satuan Pendidikan Kemandirian Guru dan Kepala Sekolah. Jakarta : Bumi Aksara

Peraturan Pemerintah nomor 19 tahun 2005 tentang Standar Nasional Pendidikan

Sugiyono. 2012. Memahami Penelitian Kualitatif. Bandung : Alfabeta 2013. Cara Mudah Menyusun Skripsi, Tesis dan Disertasi. Bandung : Alfabeta

Undang - undang No. 20 Tahun 2003 tentang Sistem Pendidikan Nasional

Wahidmurni. 2008. Penelitian Tindak Kelas : Dari Teori Menuju Praktik, disertai contoh hasil PTK. Malang : UM Press 